\title{
HUELLAS DE ICONOGRAFÍA INDÍGENA EN LOS MANUSCRITOS LITÚRGICOS MESOAMERICANOS DEL SIGLO XVI
}

\author{
TRACES OF INDIGENOUS ICONOGRAPHY: LITURGICAL MANUSCRIPTS \\ OF MESOAMERICA / $16^{\text {TH }}$ CENTURY)
}

HERÉNDIRA TÉllEZA

Las obras litúrgicas en lenguas indígenas contienen valiosa información histórica, cultural y lingüística sobre los pueblos mesoamericanos de los primeros años de la evangelización novohispana. Por su naturaleza canónica pertenecen a una tradición artística que se remonta a los primeros años del cristianismo y que fue muy cultivada durante la Edad Media y el Renacimiento: los códices litúrgicos. Al entrar en contacto la tradición católica con culturas totalmente diferentes, como las mesoamericanas, se originaron obras de carácter híbrido. En el caso de los diversos evangeliarios, sermonarios y santorales en lenguas mesoamericanas del siglo XVI, se conservan entre sus páginas, huellas de la iconografía indígena, tal como se podrá ver en los ejemplos que se presentan a continuación.

Palabras clave: Manuscritos litúrgicos, Escribas indígenas, Letras capitulares, Iconografía mesoamericana.

The liturgical works in indigenous languages contain valuable historical, cultural, and linguistic information about the Mesoamerican peoples of the first years of the novohispanic evangelization. Because of their canonical features they are part of an artistic tradition that dates to the early years of Christianity and that was widely practiced during the Middle Ages and the Renaissance: the liturgical codices. As in other artistic fields, the European catholic tradition, upon meeting completely different cultures, such as Mesoamerican cultures, yielded hybrid works. In the case of the different books of gospels, books of sermons, and books of saints in Mesoamerican languages of the XVI century, these keep in their pages traces of indigenous iconography, as the examples in this paper show.

Keywords: Liturgical manuscripts, Indigenous scribes, Initial letters, Mesoamerican iconography.

\section{INTRODUCCIÓN}

Culturas distintas convergieron en el Nuevo Mundo para dar paso a lo que, a la postre, serían las naciones americanas: las indígenas u originarias y la cristiana grecolatina, esta última pasada por el tamiz del humanismo renacentista. La construcción y definición del carácter propio de estas identidades americanas se forjó a partir de diversos rasgos, por lo que en ocasiones resulta difícil elucidar de qué cultura provienen.

En la Nueva España, la fusión cultural permitió que las obras más representativas de la cultura griega y latina o del cristianismo llegaran a ser moldeadas bajo formas indígenas, que las tradiciones vernáculas se europeizaran y que lo europeo antiguo se indigenizara (Reyes-Valerio 1989a, Gruzinski 2016: 29ss.). De este intercambio cultural surgieron otras formas de expresión y se forjaron nuevas obras a partir de los elementos diversos (Mundy 2018). Como muestra de este intercambio tenemos creaciones literarias, plásticas, arquitectónicas, entre otras.

En este artículo se analizará el caso específico de las obras litúrgicas mesoamericanas, ${ }^{1}$ entendidas exclusivamente como los textos que se utilizaban en las ceremonias litúrgicas: misales, leccionarios y obras

A Heréndira Téllez, Catedrática ConACYT, México. orcid: 0000-0002-5252-0054. E-mail: herendira.tellez@gmail.com 
homiléticas que conservan, entre sus páginas, huellas de la iconografía indígena.

Entre estas obras sobresalen los evangeliarios, que contienen las lecturas bíblicas para los domingos y fiestas, y que son fundamentales en la ceremonia de la misa. En ellos, además de la traducción de textos bíblicos a diversas lenguas mesoamericanas como el náhuatl, otomí y purépecha, destacan las ilustraciones en forma de letras capitulares (fig. 1) que reproducen imágenes de obras litúrgicas europeas, las que con el tiempo adquirieron rasgos mesoamericanos. En este artículo se abordará dicho cambio en las ilustraciones para demostrar que los amanuenses introdujeron figuras representativas de su propia cultura.

\section{DE LOS CÓDICES MINIADOS MEDIEVALES A LOS MANUSCRITOS LITÚRGICOS MESOAMERICANOS²}

Desde sus primeras manifestaciones, los códices litúrgicos-codices liturgici antiquiores-representan una de las fuentes fundamentales para el conocimiento de la iconografía católica, así como de la propia historia y evolución del culto sacramental, pues en ellos se encuentran vestigios de las más primitivas tradiciones cristianas. Durante siglos, estas primeras obras fueron el modelo para ritos y ceremonias, pero también para creaciones artísticas, sobre todo en aquellos lugares donde no existía una tradición cristiana. Al tratarse de obras canónicas, tanto los textos como las ilustraciones reproducidos intentaban respetar los modelos originales, aunque con el paso del tiempo adquirieran características innovadoras (Burckhardt 2006: 5-7).

Aquellas obras de la Antigüedad, conservadas en forma de rollos o fragmentos papiráceos y códices -tanto en formato pequeño como en 'ediciones de lujo' en hebreo, griego y latín, escritas en letra uncial (Roberts 1979: 10ss.)-, se convirtieron en textos protocanónicos tras el Edicto de Milán, promulgado por los emperadores Constantino y Licinio, en el año 313 DC. De igual forma, con la implantación del cristianismo como religión oficial en el Imperio romano, realizada por Teodosio I, el Grande, en 380 DC, que seguían fundamentalmente los acuerdos del Concilio de Nicea (Blázquez Martínez 1997: 56, Piñero 2007: 169ss.), y luego con el resurgimiento de Bizancio, los códices miniados religiosos adquirieron gran relevancia. Más tarde, con la expansión de la nueva

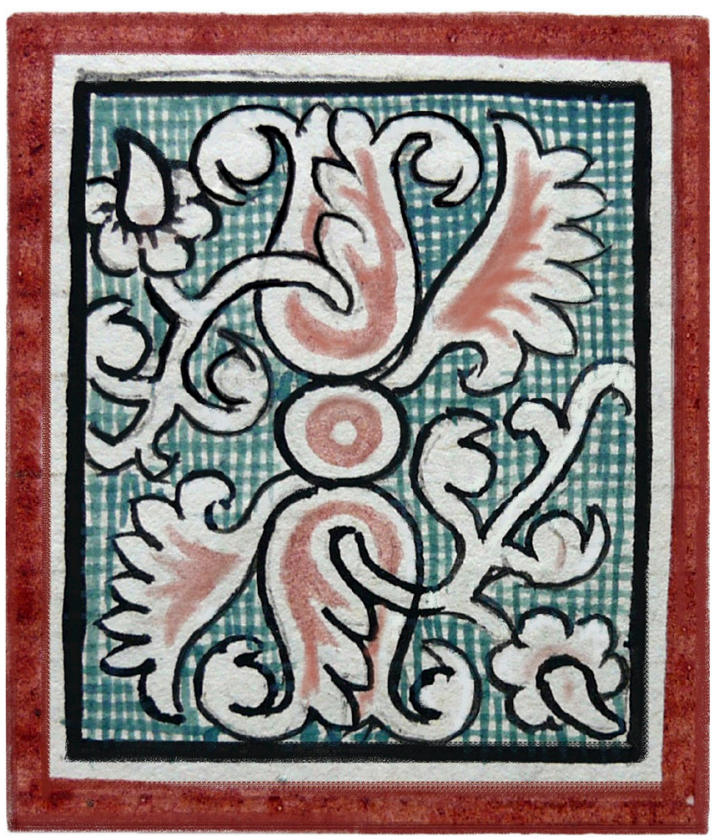

Figura 1. Letra capitular: ms. Tl f. 185v. Figure 1. Initial letter: ms. Tlf. $185 \mathrm{v}$.

religión fueron llevados hacia lugares como Galia, Hispania y Bretaña, donde fueron incorporados elementos locales. Durante toda la Edad Media se copiaron en los scriptoria medievales numerosos manuscritos litúrgicos, algunos miniados, con letra carolina, principalmente latín, aunque el griego (fig. 2) se siguió utilizando dentro de los límites del Imperio bizantino (Gamber 1968, Burckhardt 2006: 7ss.). ${ }^{3}$

Las imágenes representadas en los códices litúrgicos podían ser ilustraciones de folios completos, parciales o letras capitulares con escenas propias del cristianismo, y a menudo referencias bíblicas, como la Natividad de Cristo, los Reyes Magos, David y Goliat, las Bodas de Caná, entre otras (fig. 3). ${ }^{4}$ Sin embargo, los dibujos de las capitulares contenían las más diversas figuras: simples motivos florales, formas geométricas, además de ilustraciones zoo y fitomorfas (fig. 4), así como seres mitológicos, tales como dragones o sirenas (Gameson 2011). ${ }^{5}$

Este tipo de diseños los encontramos en los manuscritos de cualquiera de los diversos subgéneros que conforman el género litúrgico: antifonario, breviario, calendario, homiliario, evangeliario, libro de horas, devocionario, misal oracional, ordinario pasionario, penitencial, pontifical, procesional, responsorio, sa- 


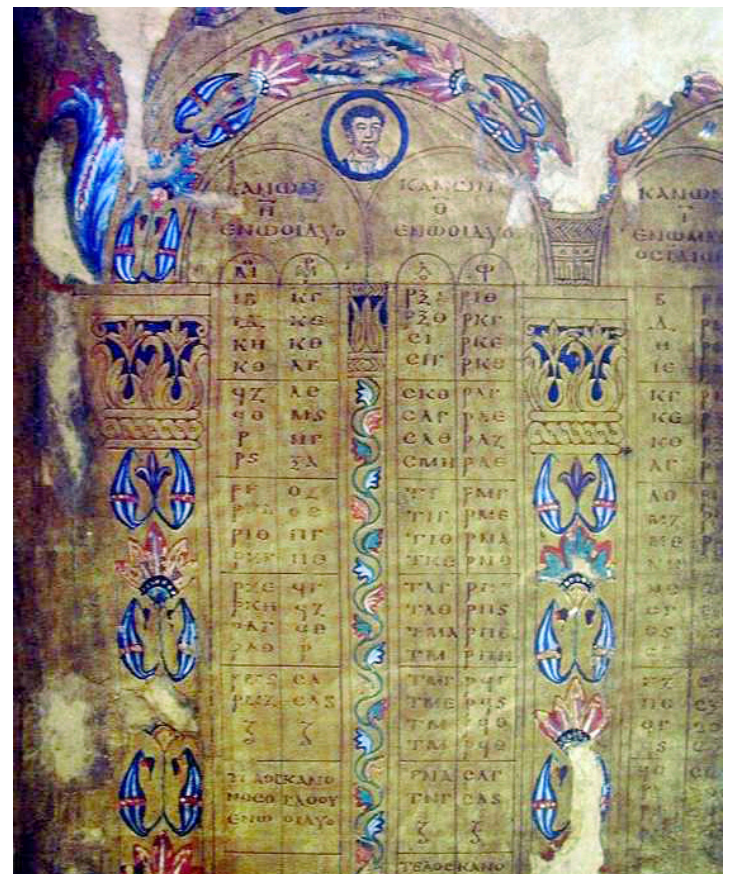

Figura 2. London Canon Tables, ms. Add MS 5111, British Library, siglos VI-VII. (Wikimedia Commons. Public Domain). Figure 2. London Canon Tables, ms. Add MS 5111, British Library, VI-VII centuries (Wikimedia Commons. Public Domain).

cramentario, sermonario y santoral, además de los cantorales (Sánchez Mairena 2015).

La continuidad en los elementos iconográficos de los manuscritos litúrgicos se observa incluso en lugares donde el cristianismo se convirtió en una religión nueva. Tal es el caso de Nueva España, donde se realizaron numerosos manuscritos en lenguas vernáculas y con temática religiosa, destinados a la población nativa, ${ }^{6}$ como los evangeliarios en náhuatl, otomí, purépecha (Téllez \& Baños 2018).

Estas obras, fruto de un complejo proceso de composición iniciado por Pedro de Gante $(+1572)$, Arnaldo Bassacio $(+1542)$ y otros frailes del Colegio de Tlatelolco, como Bernardino de Sahagún (14991590) y Alonso de Molina (1514-1585), habrían contado también con la participación de varios colegiales

Figura 4. Evangelio bretón, ms. Egerton 609, fol. 8r, British Library, siglo Ix. (Public Domain). Figure 4. Breton Gospel Book, Egerton ms. 609, p. 8r, British Library (IX century) [Public Domain].

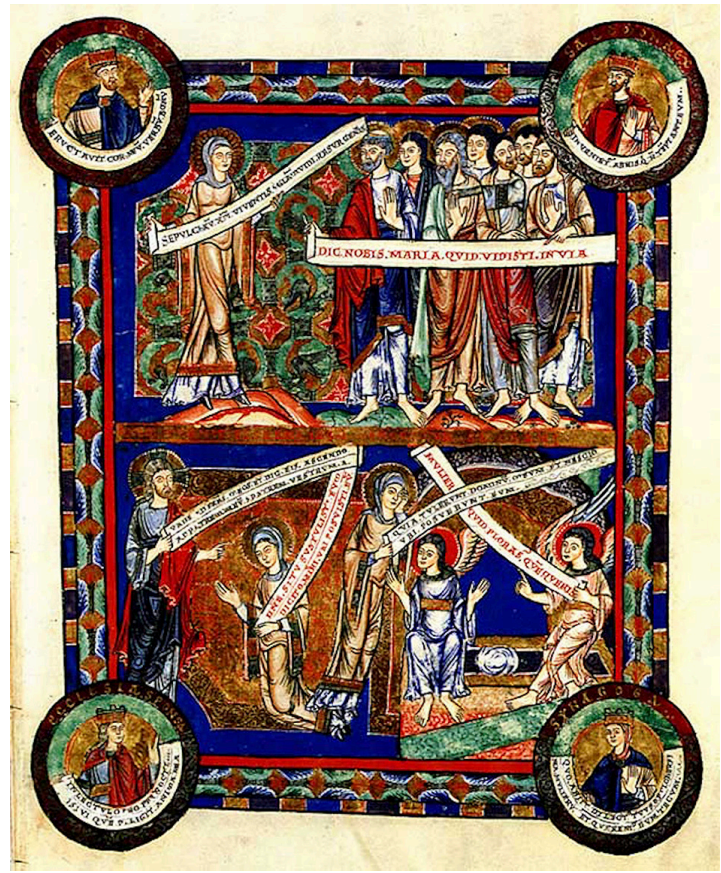

Figura 3. Evangeliario de Enrique, el León, duque de Sajonia, ca. 1175. (Public Domain). Figure 3. Gospel book of Henry the Lion, Duke of Saxony, circa 1175 (Public Domain).

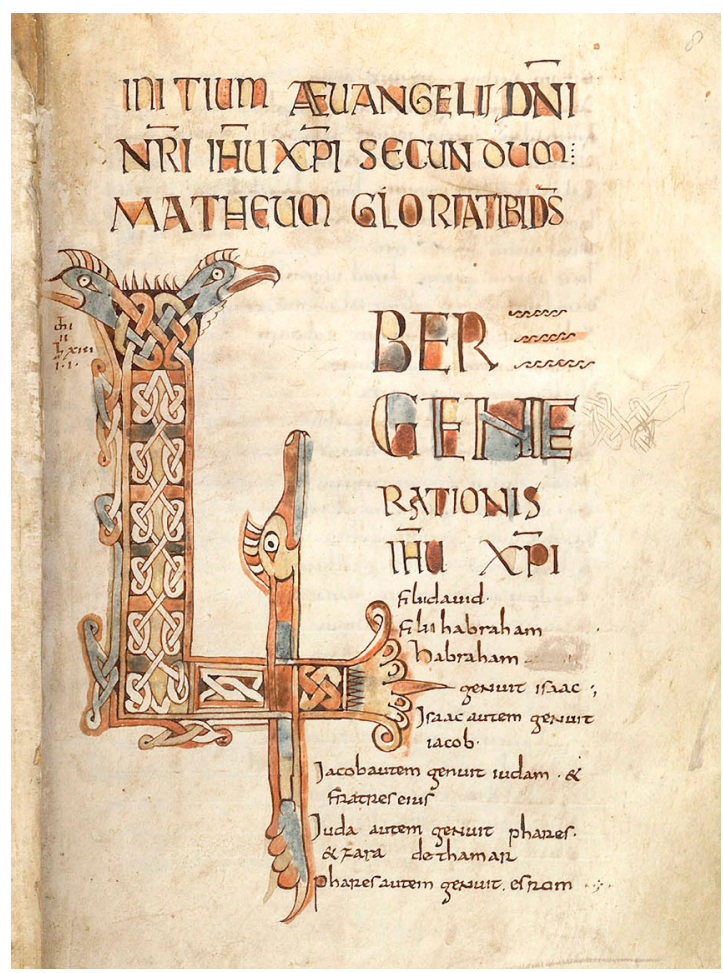


indígenas, como traductores y amanuenses, quienes, aculturados por aquellos, ${ }^{7}$ fueron de gran ayuda en la empresa evangelizadora. La estrecha colaboración entre frailes y colegiales habría dado como resultado obras de tradición europea vertidas a lenguas indígenas, como las Sagradas Escrituras, las Fábulas de Esopo en náhuatl (Téllez 2016), y otros tratados fundamentales del catolicismo, como el Contemptus mundi (Tavárez 2013), por citar algunos ejemplos.

Fray Jerónimo de Mendieta (1525-1604), a finales del siglo XVI, describía de manera muy precisa la forma en que Gante, en el colegio de San José de los Naturales (ca. 1526), había preparado a los jóvenes indígenas en el arte de la escritura y cómo más tarde llegarían a ser amanuenses expertos del scriptorium franciscano:

\footnotetext{
No menos habilidad mostraron para las letras los indios, que para los oficios mecánicos... En el segundo año que les comenzaron a enseñar, dieron a un muchacho de Tezcuco por muestra una bula y sacóla tan al natural, que la letra que hizo parecía el mismo molde... Después se fueron haciendo muy grandes escribanos de todas letras, chicas y grandes, quebradas y góticas. Y los religiosos les ayudaron harto a salir escribanos, porque los ocupaban a la continua en escribir libros y tratados que componían o trasuntaban de latín o romance en sus lenguas de ellos (Mendieta 1870 [1596]: Libro IV, Capítulo 14).
}

Fray Bernardino de Sahagún (1577: Libro II, Prólogo) relataba, igualmente, la ayuda que le habían prestado los colegiales tlatelolcas trilingües en la elaboración de sus diversos tratados, como la Historia General, y mencionaba la pericia de los escribanos que sacaban "de buena letra" sus obras. El mismo elogio a los colegiales tlatelolcas lo haría fray Juan Bautista Viseo (1606: Prólogo), quien, además de certificar el dominio de los indígenas en las lenguas latina y castellana, hablaba de la importancia de los amanuenses en el proceso de transcripción, copia e incluso formación de los impresos (Tavárez 2013: 208).

Con todo, es realmente poco lo que se conoce sobre el proceso de edición de los manuscritos fabricados en el scriptorium franciscano. Las nuevas evidencias textuales señalan que, por lo menos, la parte de códices litúrgicos, en específico los evangeliarios, fueron producto de una organización editorial bien definida, y que, guardando las debidas proporciones, el colegio de Tlatelolco habría funcionado a la usanza de los antiguos scriptoria medievales (Téllez 2019).

Tal como sucedió con otras formas artísticas (Mundy \& Leibsohn 2012, Mundy 2018), los códices

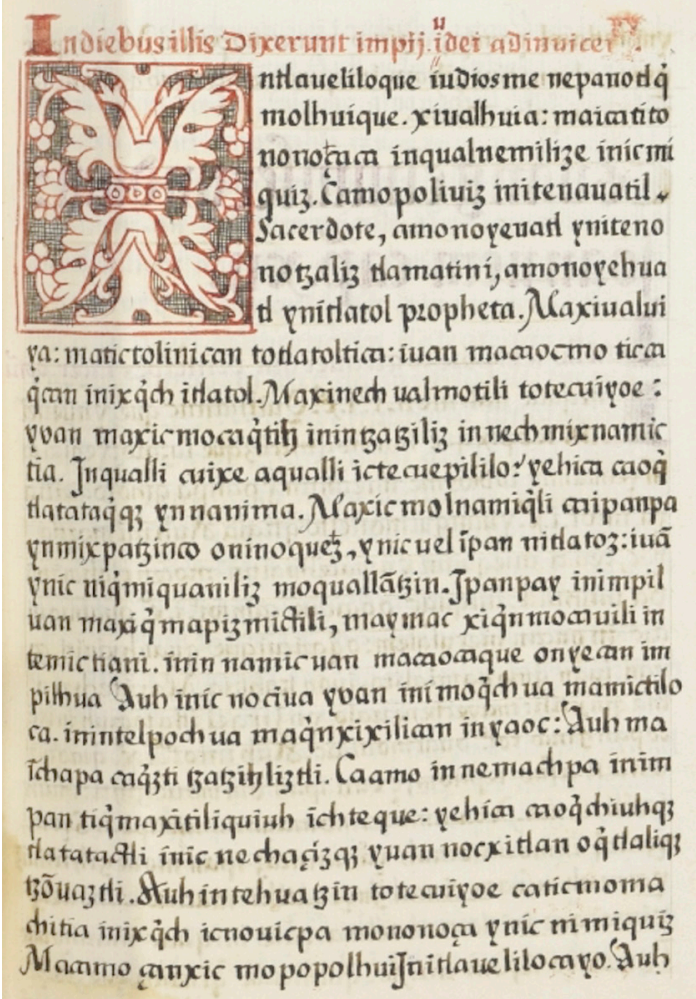

Figura 5. Evangeliario en lengua mexicana, ms. Tl, f. 85r (ca. 1544). Figure 5. Gospel book in Mexicana language, ms. Tl, p. 85 r (circa 1544).

litúrgicos en lenguas mesoamericanas del siglo XVI presentan reminiscencias de la antigua cultura prehispánica. En este sentido, es necesario recordar que la evangelización de la Nueva España ofrece características particulares, fruto de una tradición híbrida en la cual coexisten elementos típicamente cristiano-europeos con rasgos mesoamericanos. Estos cruces bidireccionales se pueden encontrar en distintos ámbitos -arquitectónico, escultórico o pictográfico-, en donde sobresalen las representaciones zoomorfas o fitomorfas de apariencia prehispánica (Reyes-Valerio 1989a).

En el caso de los códices litúrgicos indoamericanos, la presencia indígena no se limitará a la utilización de antiguas técnicas de trabajo, sino que introducirá elementos iconográficos del pasado mesoamericano, de la cosmovisión prehispánica e incluso de la antigua religión, a través de los motivos decorativos de los manuscritos, especialmente los que se encuentran en las letras capitulares que -tal como en los códices medievales 
(López Ramírez 2015: 23ss.)- se utilizan para destacar el inicio de libro, de capítulo o de párrafo.

El estudio de estas iniciales en los códices litúrgicos mesoamericanos se ha realizado a partir de los diversos ejemplares de las Epístolas y Evangelios (Incipiunt Epistolae et Evangelia traducta in linguam mexicanam), y la traducción en náhuatl de las lecturas bíblicas para el ciclo litúrgico que se utilizó durante los siglos XVI y XVII (Téllez \& Baños 2018). Si bien, los ejemplares más importantes de este corpus se remontan a la primera mitad del siglo xvi (fig. 5), existen copias posteriores, casi de finales de siglo. La diferencia entre las etapas de copia y el lugar donde se transcribieron puede advertirse por los elementos codicológicos. En este sentido, solo se han rescatado los ejemplares que parecen provenir del mismo scriptorium franciscano. Junto con los evangeliarios propiamente dichos, se han revisado otras obras de contenido religioso, como las dos versiones del Contemptus mundi y los sermonarios, todos en náhuatl.

\section{ICONOGRAFÍA INDÍGENA EN LOS CÓDICES LITÚRGICOS NOVOHISPANOS}

Tal como se ha dicho, además de los elementos propiamente europeos que adornan los códices litúrgicos mexicanos, en ellos también se hallan diversos tipos de figuras que remiten a la tradición prehispánica. Es importante señalar que estas reminiscencias parecen tomadas de los mismos monumentos prehispánicos, es decir, que tienen un sustento epigráfico o arqueológico, como se verá.

Algunos de los símbolos iconográficos más constantes en las ilustraciones provienen de los calendarios -tonalamatl en náhuatl o tzolk'in en maya- tanto del tonalpohualli, como del xiuhpohualli. ${ }^{8}$

El tonalpohualli era el calendario ritual mesoamericano de 260 días, dividido en trece 'meses', cada uno con veinte 'días' o signos (tonalli), ordenados de la siguiente forma: 1 cipactli, cocodrilo; 2 ehecatl, viento; 3 calli, casa; 4 cuetzpallin, lagarto; 5 coatl, serpiente; 6 miquiztli, muerte; 7 mazatl, venado; 8 tochtli, conejo; 9 atl, agua; 10 itzcuintli, perro; 11 ozomatli, mono; 12 malinalli, hierba o paja; 13 acatl, caña; 14 ocelotl, ocelote; 15 quauhtli, águila; 16 cozcaquauhtli, zopilote; 17 ollin, sol o movimiento; 18 tecpatl, pedernal; 19 quiahuitl, lluvia; 20 xochitl, flor (Séjourné 1983: 13-36).
Este calendario, así como los signos que lo conforman (fig. 6), fue conocido ampliamente por los franciscanos, quienes criticaban su uso ritual, tal como hiciera Sahagún en el libro cuarto de la Historia General, llamado 'De la astrología judiciaria o adivinatoria', en el que explicaba que este calendario servía para determinar la fortuna de quien nacía bajo él, lo cual consideraba una práctica de 'nigromancia'. Sin embargo, y a pesar de las advertencias, algunos de estos símbolos van a aparecer pintados en los manuscritos litúrgicos:

Estos naturales, de toda Nueva España tuvieron y tienen gran solicitud en saber el día y la hora del nacimiento de cada persona para adivinar las condiciones, vida y muerte de los que nacían; los que tenían este oficio se llamaban tonalpohuque, a los cuales acudían como a profetas, cualquiera que le nacía hijo, hija para informarse de sus condiciones, vida y muerte. Estos adivinos no se regían por los signos, ni los planetas del cielo, sino por una instrucción, que, según ellos dicen, se la dejó Quetzalcoatl, la cual contiene veinte caracteres, multiplicados trece veces, por el modo que en el presente libro se contiene. Esta manera de adivinanza en ninguna manera puede ser lícita, porque ni se funda en la influencia de las estrellas, ni en cosa ninguna natural, ni su círculo es conforme al círculo del año, porque no contiene más de doscientos y sesenta días los cuales acabados tornan al principio. Este artificio de contar o es arte de nigromántica o pacto y fábrica del demonio, lo cual con toda diligencia se debe desarraigar (Sahagún 1577: Libro Iv, Prólogo, fol. 240v). ${ }^{9}$

La ambigüedad sobre el uso de estos signos se advierte en las disputas entre los franciscanos. Sahagún criticó específicamente a fray Toribio de Motolinía por "loar palabra por palabra una cosa tan mala y tan llena de idolatría", al hablar del antiguo calendario:

Por las ruedas aquí antepuestas, cuentan los indios sus días, semanas, meses, años, olimpiadas, lustros, indiciones y hebdómadas [...] y según parece los indios que la compusieron y sabían ciertamente se mostraron filósofos naturales, solamente faltaron el bisiesto, pero también pasó el gran sabio filósofo Aristóteles y su maestro Platón, y otros muchos sabios que no lo alcanzaron. $Y$ es de saber que en este calendario no hay cosa de idolatría, y esto se puede de alabar por muchas razones, pero bastará decir una, y es que en esta tierra no ha muy muchos años que comenzaron las idolatrías, y este calendario es antiquísimo, y si los nombres de los días, semanas y años y sus figuras son de animales y de bestias y de otras criaturas, no se deben maravillar, pues si miramos los nuestros también son de planetas y de dioses que los gentiles tuvieron, y pues que aquí se escriben muchos ritos, ficciones y antiguos sacrificios una cosa tan buena y de tanto primor y verdadera que estos naturales tuvieron no es razón de reprobarla, pues sabemos que todo bien y verdad, quien quiera que la diga es del Espíritu Santo (Sahagún 1577: Libro Iv, fol. 77r). 


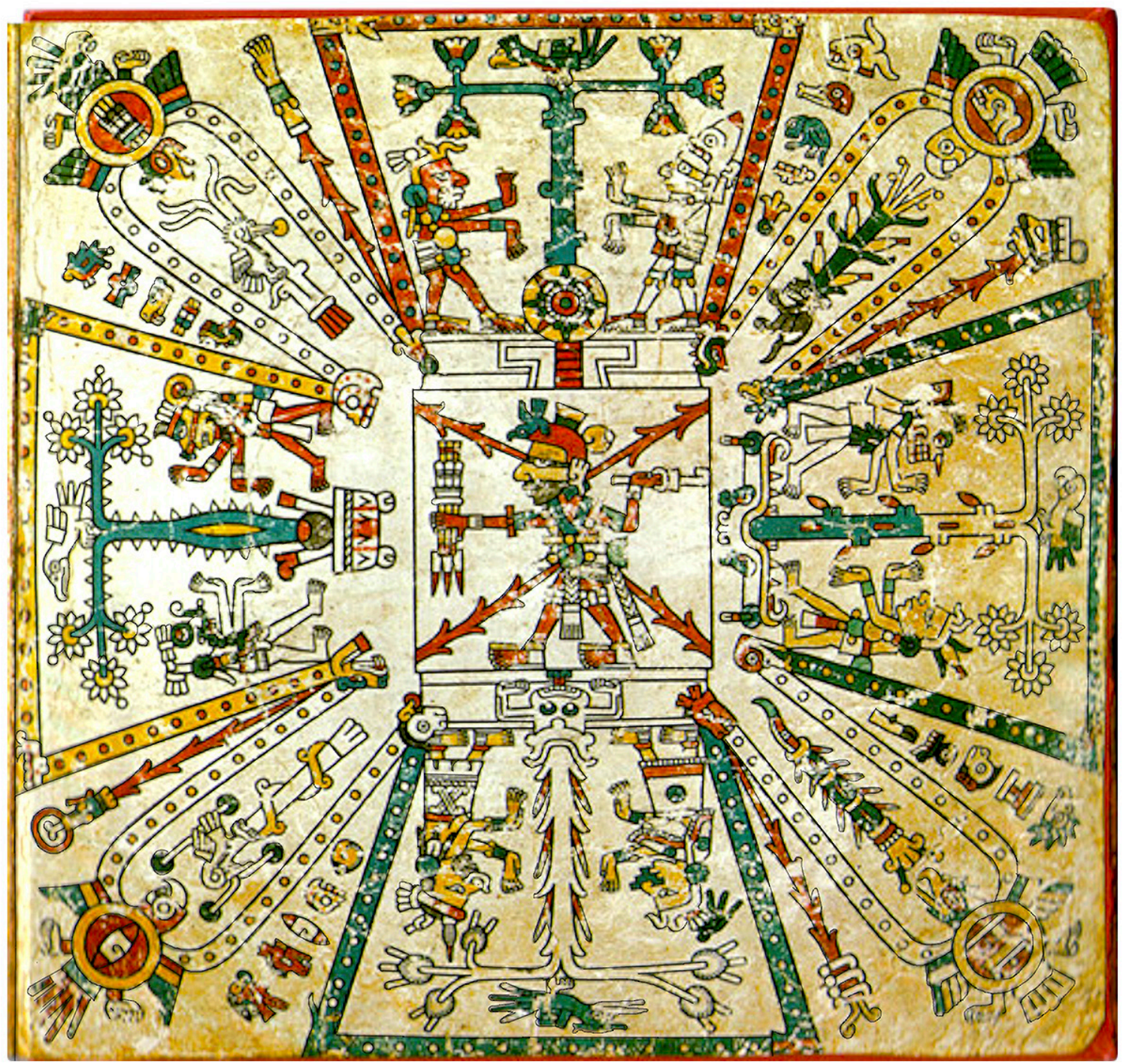

Figura 6. Códice Fejérváry-Mayer, lám. 1. (Public Domain). Figure 6. Fejérváry-Mayer Codex, sheet 1. (Public Domain).

Aun así, la ortodoxia se impuso y el calendario mexica fue rechazado más tarde por los frailes. De hecho, hacia 1596, fray Jerónimo de Mendieta, además de narrar el origen mítico del calendario, ${ }^{10}$ advertía el peligro de tener estos 'signos de abusión' en las construcciones católicas (Reyes-Valerio 1989b: 75):

Este calendario sacó cierto religioso en rueda con mucha curiosidad y sutileza, conformándolo con la cuenta de nuestro calendario y era cosa bien de ver [...] Más porque era cosa peligrosa que anduviese entre los indios, trayéndoles a la memoria cosas de su infidelidad e idolatría antigua, porque cada día tenían su fiesta e ídolo a quien la hacían, con sus ritos y ceremonias; por tanto, con mucha razón fue mandado que el tal calendario se extirpase del todo [...] Aunque es verdad que algunos de los indios viejos y otros curiosos tienen aún al presente en la memoria los dichos meses y sus nombres. Y los han pintado en algunas partes; en particular en la portería del convento de Cuautinchan tienen pintada la memoria de cuenta que ellos tenían antigua con estos caracteres o signos (Mendieta 1870: Libro II, Capítulo 14).

Cuautinchan no sería el único monasterio donde se pueden apreciar rastros de iconografía prehispánica, pues han sobrevivido representaciones en Tepeapulco, Culhuacán, Xochimilco, Huejotzingo, entre otras construcciones del siglo XVI (Reyes-Valerio 1989b: 75). Además de las numerosas muestras de estos signos 


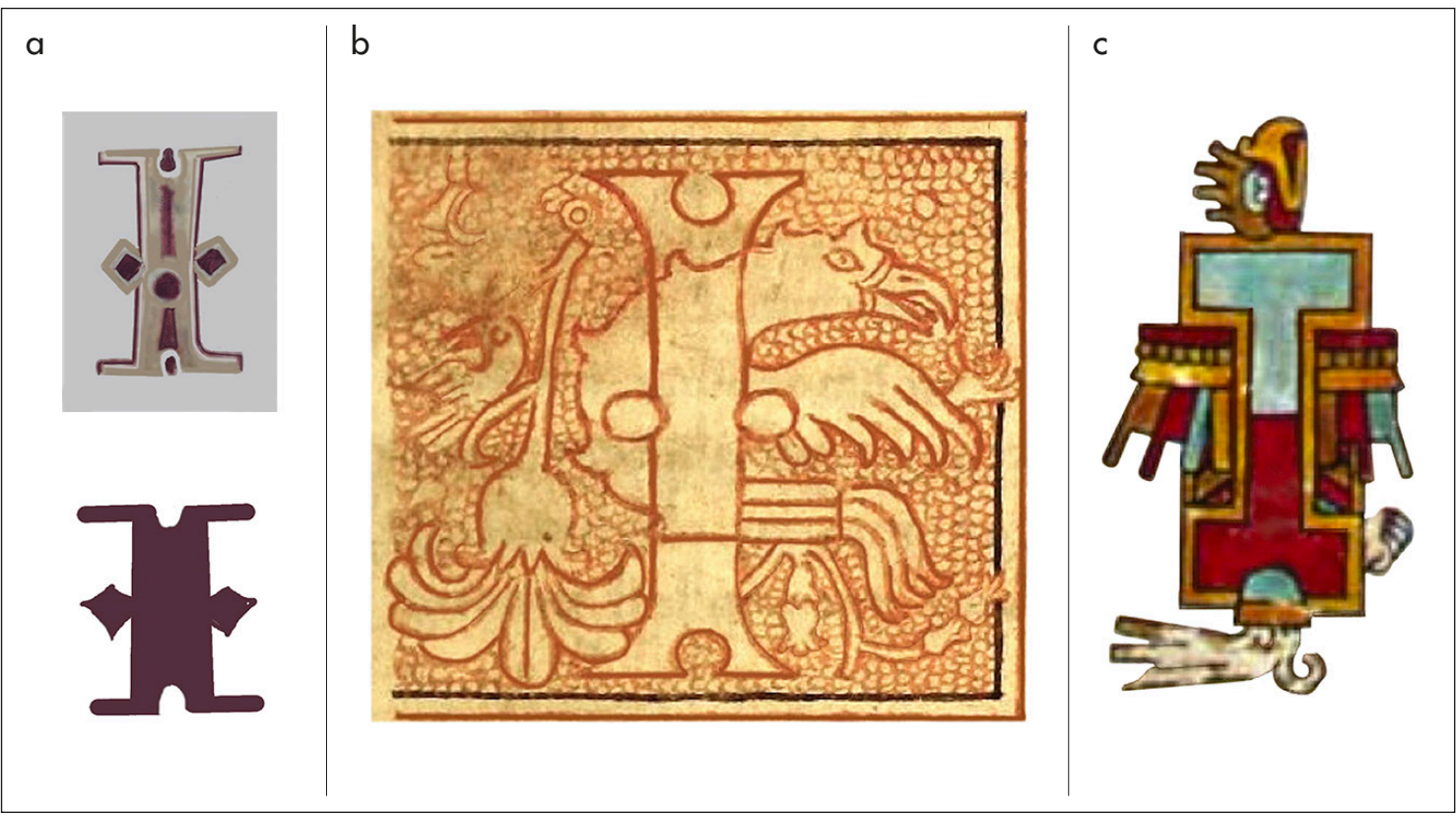

Figura 7. Capitulares: a) ms. MS, 86r, ms. Mx. 4r; b) ms. Bw, 1r; c) Códice Vindobonensis, lám. 7. Figure 7. Initial letters: a) ms. MS, $86 r, m s . M X .4 r ; b)$ ms. BW, $1 r ; \boldsymbol{c}$ ) Vindobonensis codex, sheet 7.

que se conservan en los conventos e iglesias y en las miniaturas de los códices litúrgicos mesoamericanos hasta ahora, se han encontrado representaciones o reminiscencias de los signos de coatl, cipactli, calli, ollin, acatl, y también de tlachco, elotl y atl tlachinolli, entre otras.

El ollamaliztli o 'juego de pelota' fue una de las prácticas mesoamericanas más destacadas y que mayor relevancia cultural tuvo en toda la región, con un "profundo sentido religioso, un ritual cargado, un gran uso como medio adivinatorio" (López Austin 1967: 7). Su importancia se puede advertir en la gran cantidad de canchas, tlachco, que se han encontrado en la región mesoamericana, así como la propia representación del juego en numerosos murales y códices (López Austin 1967: 61-63, Uriarte 1992, Taladoire 2017).

Sin entrar en detalles sobre los elementos rituales y culturales a los que se asociaba, para este análisis baste señalar que la cancha o tlachco del juego de pelota estaba constituida por algunos componentes arquitectónicos fijos: dos largas paredes que en el centro tenían marcadores redondos, tlachtemalacatl, por donde debía pasar la pelota, y al final de la pista se encontraba una pared, de cada lado, dando una forma de 'I' a la cancha (De la Garza \& Izquierdo 1980).
En las numerosas representaciones de murales y códices mesoamericanos que se conservan, se recrea esta estructura: la de una I con dos volutas a la mitad, señalando los tlachtemalacac. Además, el juego de pelota suele estar asociado con otros elementos pictográficos, y tlachco, como factor fonético, a veces sirve para crear topónimos y antropónimos.

Así, de manera muy sucinta, la importancia del símbolo tlachco queda demostrada en la iconografía mesoamericana. No es extraño, pues, que los jóvenes tlahcuilohqueh o amanuenses del scriptorium franciscano utilizaran este símbolo en las letras capitulares (fig. 7), tal como ya lo había advertido Moreno de los Arcos al señalar que algunos de los manuscritos litúrgicos de la Biblioteca Nacional de México, como "el Sermonario sahaguntino tiene una característica desusada: algunas capitulares son motivos prehispánicos; por ejemplo, la I mayúscula es un coloreado juego de pelota" (Moreno de los Arcos 1969: 156).

Este rasgo lo podemos encontrar en diversas obras litúrgicas, como el Contemptus mundi, ejemplar de la Biblioteca John Carter Brown (fol. 1r), o en la Imitación de Cristo en náhuatl (fol. 2r), manuscrito escurialense. En todos los casos, los estilos coinciden: un tlachco con los tlachtemalacac a los lados, cuyas representaciones 

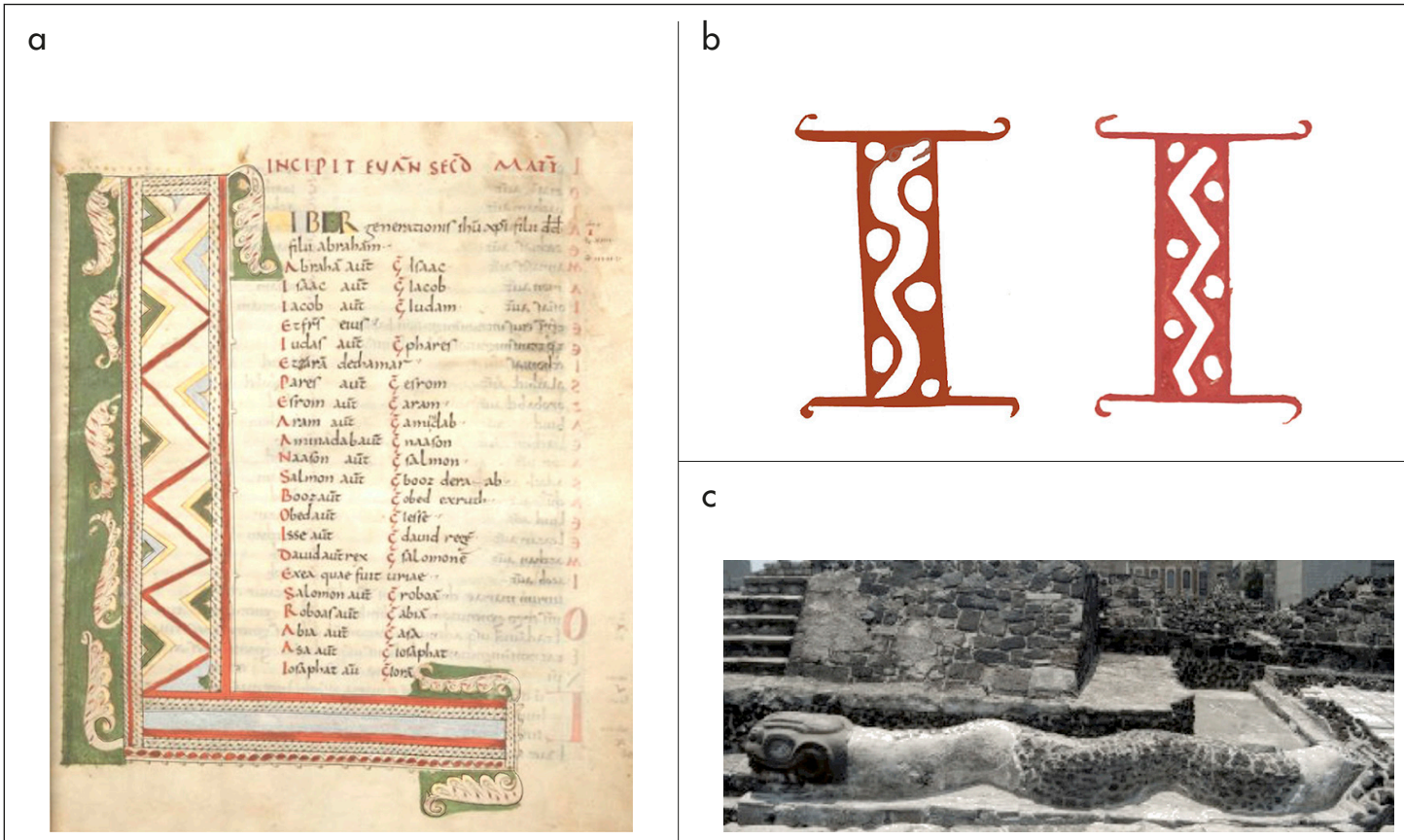

Figura 8: a) Evangelios, ms. Add. 40000, f. 13r, siglo x. (British Library. Public Domain); b) Capitular Coatl, ms. Mt.; c) Templo Mayor, México. Figure 8: a) Gospel books Ms. Add. 40000, p. 13 r, (x century), British Library (Public Domain); b) Coatl Initial letter, ms. Mt.; c) The Great Temple, Mexico City.

coinciden con otros tipos de documentos mesoamericanos, como el Códice Vindobonensis. En el caso de las capitulares litúrgicas, el tlachco, con la representación de la cancha en forma de I y las volutas laterales, está acompañado en el Contemptus por un águila -aunque esta es híbrida, con rasgos europeos y prehispánicos-; en la Imitatio presenta diversos motivos geométricos y florales. ${ }^{11}$ Esta representación, aunque simplificada y estilizada, también se encuentra en otros manuscritos, en los que solo se observan los marcadores y el campo de juego.

Hay que señalar, sin embargo, que, si bien tlachco es un elemento innovador de la tradición indocristiana o indolatina en los evangeliarios, los rasgos zoomorfos presentan características prototípicas de la tradición europea. Baste como ejemplo la comparación con las águilas de los manuscritos medievales (fig. 4). No sabemos si en este caso, como en los códices, este símbolo combinado habría tenido algún otro significado, como una fecha o un nombre.

Coatl fue otro de los símbolos significativos en Mesoamérica. De la Garza (1984: 319) explica que para los mayas simbolizaba la "fuerza universal [...] que hace del cosmos una totalidad viviente y dinámica”; además, representa la "capacidad de procreación y de encarnar su sangre", pues es una representación fálica que "aparece en las ceremonias que propician la fertilidad de la tierra".

Para López Austin et al. (1991: 42) representa una parte de Cipactli, aquel animal mítico que "fue tronchada por dos dioses convertidos en serpientes, quienes formaron el cielo y la tierra con las dos mitades, colocando entre ellas los postes que crearon el espacio libre para la morada de los hombres". La cantidad de serpientes que aparecen en toda región mesoamericana es sobreabundante: se pueden observar labradas en piedra, en murales, en códices, en estatuillas. Por el contrario, en el contexto católico cristiano, la serpiente representa el mal primigenio (Gen 3:1), y por lo tanto, no parece un icono deseable dentro de un texto religioso. No obstante, este figura en no pocas letras capitulares de los evangeliarios: algunas veces como serpiente con todos sus atributos y otras veces de forma más estilizada, siguiendo únicamente patrones geométricos, estos últimos ya presentes en la tradición medieval (fig. 8a). 
Otros símbolos mesoamericanos están representados en las letras capitulares, aunque de forma menos obvia. Es el caso de la letra "I" que contiene algunos rasgos del signo calli, casa, (akbal, noche en maya [Séjourné 1983: 299]) que en el xiuhpohualli funcionaba como el tercer elemento de la serie de cuatro (acatl, tecpatl, calli, tochtli). En relación con el simbolismo de los puntos cardinales, a calli le correspondía el oeste (Johansson 2008: 149, 163). En el tonalpohualli, o trecena de días, calli era el decimoquinto signo y era de fortuna adversa. Se decía que "los hombres que en él nacían eran grandes ladrones, luxuriosos, tahúres, desperdiciadores y que siempre paraban en mal. Y las mugeres que en él nacían eran perezosas, dormilonas, inútiles para todo bien” (Sahagún 1577: Libro Iv, Capítulo 27, fol. 52v).

Calli se representaba iconográficamente de distintas formas, aunque contiene algunos detalles imprescindibles: el techo, casi siempre en forma de tablero-talud y en ocasiones con volutas, aunque también se encuentra en forma plana; el soporte del techo constituye un elemento diferente al techo de paja y se encuentra intermedio entre la base y depende de una pared lateral. En casi todos los testimonios epigráficos y códices conocidos, tanto del grupo mexica como del mixteco, este signo aparece combinado con otros, dando paso a numerosas combinaciones calendáricas. Thouvenot (2005) señala que el glifo de calli puede 'leerse' con otros valores, en concreto "chan-", por lo que las posibilidades de lectura son múltiples.

En el Sermonario mexicano de Bernardino de Sahagún y Alonso de Escalona, encontramos en la capitular "I" algunas características que recuerdan a calli (techo, soporte intermedio y base) combinado con un signo coatl. Cabe destacar que, quizá simplemente como coincidencia, la fecha 1 coatl [tlaxochimaco] 3 calli corresponde al 13 de agosto de 1521, día de la caída de Tenochtitlan (fig. 9).

Un motivo prehispánico más que podemos encontrar de forma velada en los evangeliarios es probablemente el cipactli, en náhuatl [ain en maya]. Este signo pertenece al tonalpohualli o calendario ritual: con ce cipactli o 1 imix se iniciaba la cuenta de los días, ya que es "el primer día de la primera de las 18 veintenas que constituyen el año en el comienzo del ciclo de 52 años" (Séjourné 1983: 223).

Como deidad, "Cipactli es el monstruo original, femenino y acuático, que según los mitos nahuas fue dividido en dos partes para formar con ellas el cielo y la

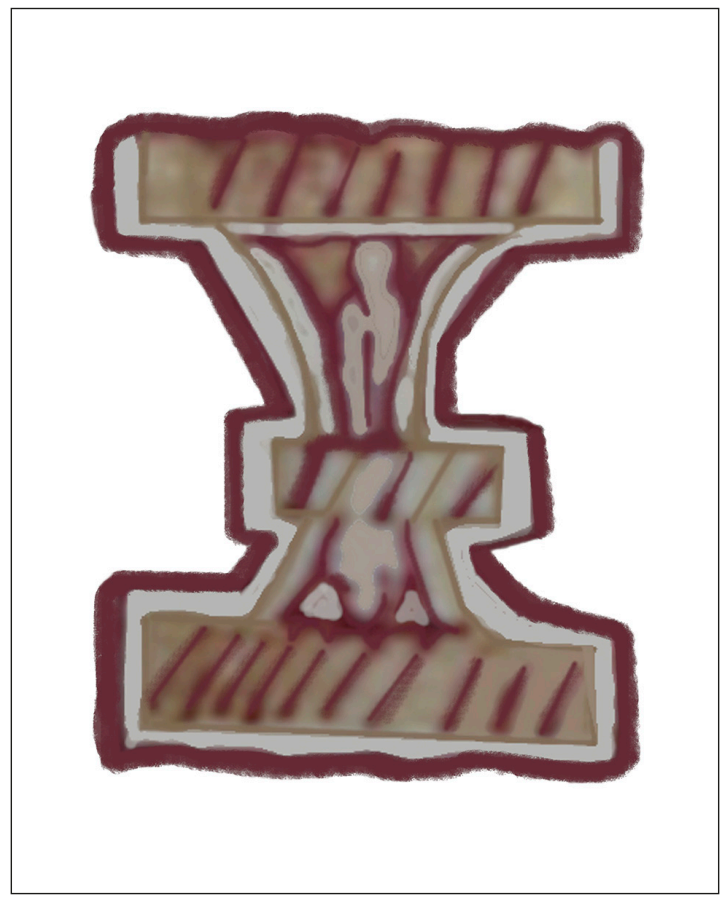

Figura 9. Capitular: ms. MS. Figure 9. Initial letter: ms. MS.

tierra”. De esta forma, en la iconografía se le representa en numerosas ocasiones como "una enorme boca hecha con las dos quijadas del cipactli juntas e invertidas" (Séjourné 1983: 213). Una característica notable de la representación en su faceta calendárica es la "falta de mandíbula, rasgo que tal vez se refiriera a la separación original del monstruo en dos mitades" (López Austin et al. 1991: 41-42), y, al igual que el anterior, este fue conocido por todas las culturas mesoamericanas.

En numerosas representaciones, cipactli, el día, "está formado por una cabeza de réptil carente de mandíbula inferior, con tres cuchillos de pedernal -blanco-rojo- a manera de dientes", y usualmente pasa "un raudal rojo por encima del ojo", además "la piel está constituida por el signo de la piedra preciosa” (Séjourné 1983: 16). Este habría tenido "una relación simbólica con el agua y el fuego" (De la Fuente 1995: 91). Algunas de estas variantes se encuentran en los distintos códices mesoamericanos, así como en los testimonios epigráficos.

En los códices litúrgicos mexicanos, cipactli parece estar representado en algunas capitulares de letra 'I' (fig. 10). La representación contiene algunos trazos característicos de los códices calendáricos, en los que solo se dibujaba la cabeza: se insinúan las líneas reptileanas, la 


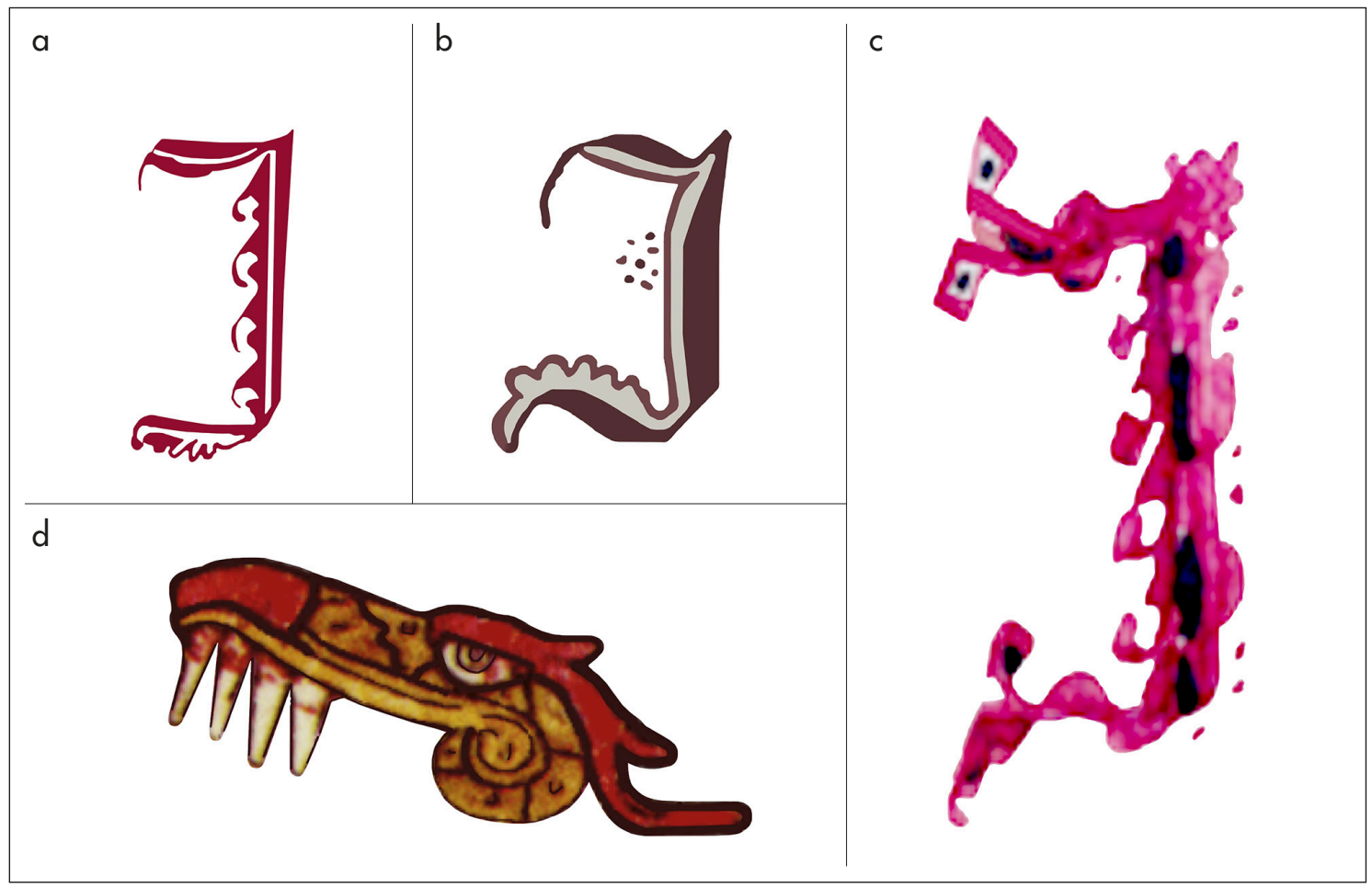

Figura 10. Capitular I: a) ms. Nw; b) ms. Tl; c) ms. Mx; d) Códice Borgia. Figure 10. Initial letter I: $\boldsymbol{a}$ ) ms. NW; $\boldsymbol{b}$ ) $m s . T l ; \boldsymbol{c}) m s . M X$; d) Borg codex.

piel se representa a través de puntos, y quizá en algunos incluso se encuentren marcas que indiquen la relación simbólica agua-fuego.

Esta letra la encontraremos en no pocos ejemplares de los evangeliarios, por lo que puede decirse que fue una letra capitular muy común en las obras litúrgicas. Sin embargo, este elemento también puede relacionarse con los códices medievales, en ellos no solo los dragones eran un motivo usual, sino que encontramos patrones abstractos similares a los mesoamericanos.

Existen numerosos ejemplos más de elementos prehispánicos que sugieren un paralelismo con los manuscritos litúrgicos novohispanos, algunos de los cuales simplemente evocan escenas de la vida cotidiana, como la representación del maíz, ${ }^{12}$ que no existía en Europa, pero se puede ver en las esculturas mesoamericanas.

En náhuatl existía una diversidad de términos para el maíz, dependiendo de sus características (color, tipo, grado de maduración, etc.), y cada uno de ellos era representado en los códices bajo diversas formas. El elotl o elote era la "mazorca de maíz verde que tiene ya cuajados sus granos", en tanto que el maíz seco, pero todavía en mazorca, era el cintli, y las hojas que cubren al maíz tierno elototomochtli (Molina 1571a: 81r; 1571b: 29v). La representación del cintli o centli se puede observar en algunos códices "conformando una figura de forma cónica que termina con una punta redondeada y que en su interior posee una serie de líneas curvadas de manera continua que se repiten en serie, que representan los granos del maíz", y servía también para el numeral centli. ${ }^{13}$ En el caso específico del evangeliario Nw, vemos los puntos que representan los granos de maíz y el elototomochtli abriéndose, por lo que sabemos que no es un maíz tierno, sino un centli (fig. 11).

Las flores, de acuerdo con Reyes-Valerio (1989b: 72), representan una forma estilizada de ollin, 'movimiento' (el símbolo xochitl, flor propiamente, no coincide con el dibujo de cuatro lados). Su "rodete central indicaría la región del centro, el xicco, omphalos u ombligo del mundo; el tlalticpac, la tierra". Los cuatro pétalos, "las cuatro direcciones o rumbos del universo", estarían también representadas en diversos evangeliarios (fig. 12). Este elemento no debe confundirse con la "cruz de San Millán", la "cruz templaria" u otras representaciones europeas. 


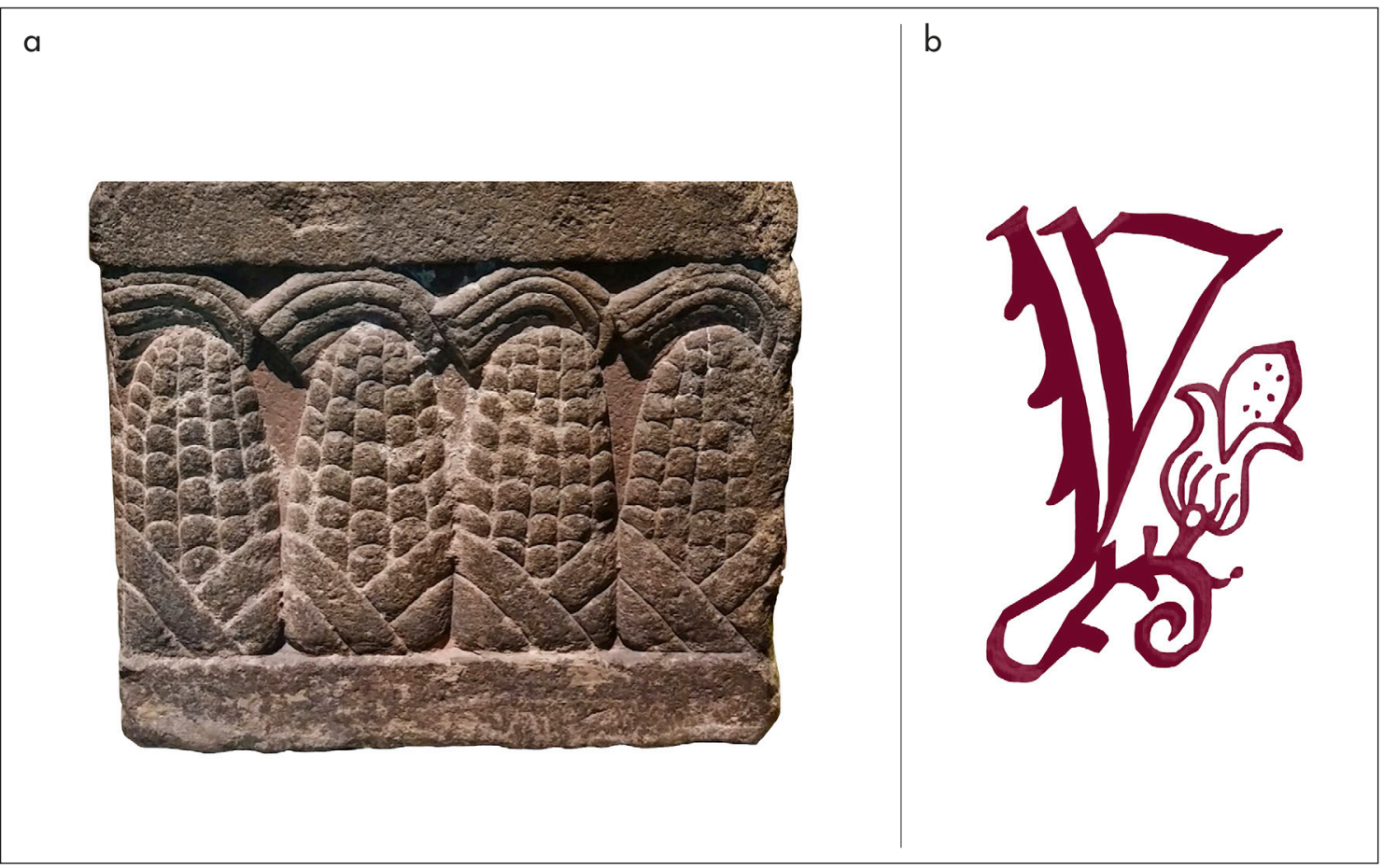

Figura 11: a) Representación del maíz en una pieza arqueológica, MNAH; b) Cintli, ms. Nw. Figure 11: a) Representation of corn in an archaeological piece, MNAH; $\boldsymbol{b}$ ) Cinti, ms. NW.

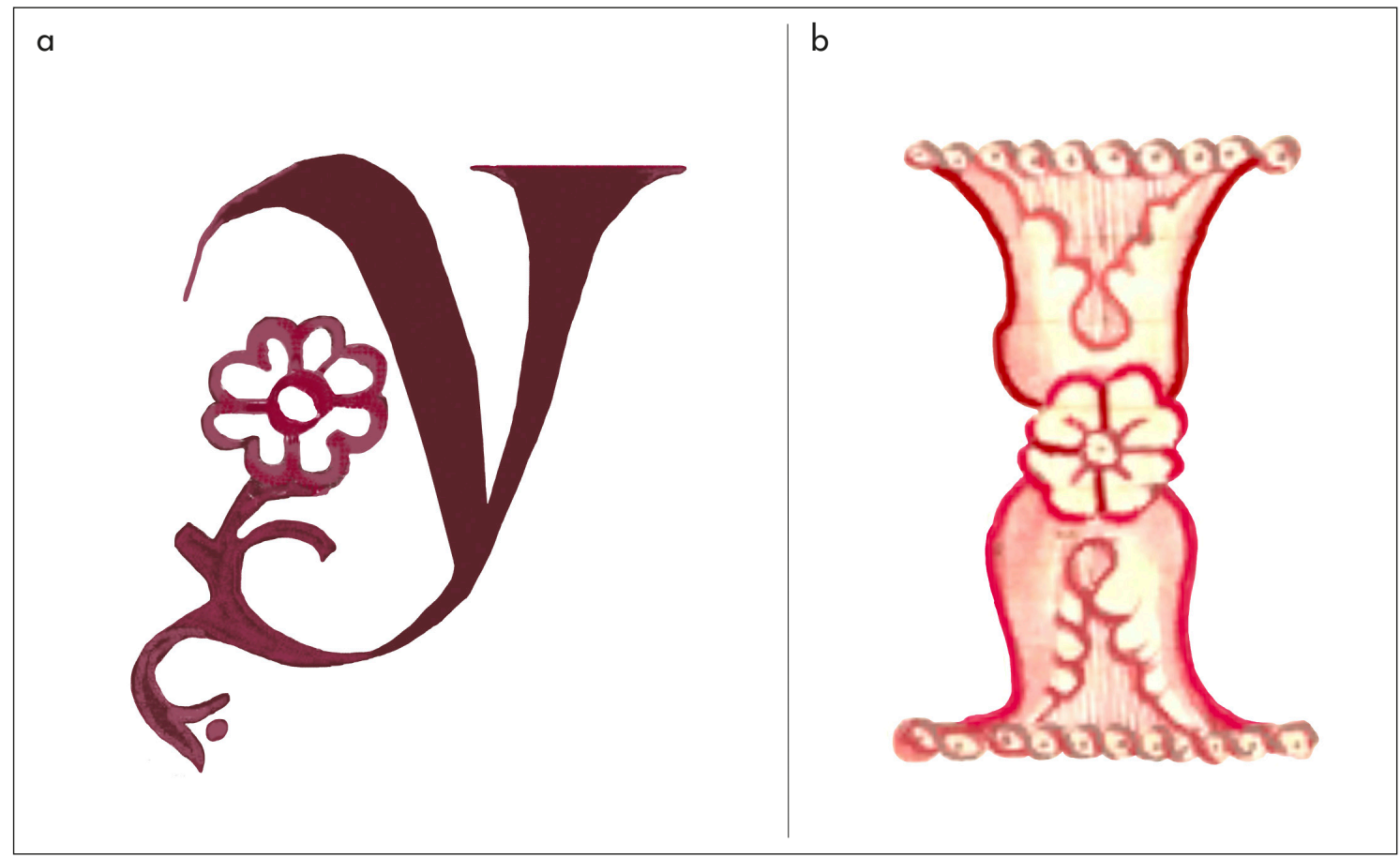

Figura 12. Capitulares flor: a) ms. Nw; b) ms. Tl. Figure 12. Flower initial letters: $\boldsymbol{a}$ ) $m s . N W ; \boldsymbol{b}$ ) $m s . \mathrm{Tl}$. 
Además, tenemos una imagen que ha causado controversia: se trata de una flor estilizada de tipo prehispánico, pero que no se ha podido identificar concretamente (fig. 13). El objeto que podría representar es todavía discutible, mas resulta destacable por dos cuestiones: primero, porque lo encontramos en dos manuscritos diferentes (fig. 14), lo que hace suponer que ambos fueron dibujados por una misma persona o por el mismo equipo; segundo, porque el ingrediente material, la tinta, con que se hizo esta capitular es completamente diferente al resto del manuscrito, algo que queda por investigar.

Finalmente, entre todos estos ejemplos de iconografía prehispánica, hay, sin embargo, uno destacable por la novedad que añade: se trata de la primera representación antropomorfa en las letras capitulares que podemos documentar y quizá hasta ahora la única en los manuscritos litúrgicos mesoamericanos (fig. 14). ${ }^{14}$ Este retrato de un hombre hincado sosteniendo una rosa de gran tamaño contiene, además, una figura similar a la flor prehispánica del manuscrito toledano (fig. 13).

Si bien esta representación es única en los manuscritos analizados, este tipo de motivos se hace muy popular en los libros impresos. Y, aunque en apariencia no hay ninguna razón histórica para pensar que el hombre que se encuentra arrodillado sea un indígena, pues lleva los usos de los frailes (el pelo, bordón, etc.), más tarde, en 1669, surgirá una imagen parecida: la de Juan Diego y la Virgen de Guadalupe (fig. 15). La comparación entre los grabados de las obras religiosas impresas y los manuscritos es todavía un asunto que debe investigarse.

\section{REFLEXIONES FINALES}

Los elementos hasta aquí analizados parecen demostrar que existen evidentes reminiscencias prehispánicas en los códices litúrgicos en lengua náhuatl, las cuales están documentadas en obras mesoamericanas originales. Si estas fueron insertadas por los amanuenses indígenas de forma intencional y permitidas por los frailes, o si eran parte de la formación de estos copistas y fueron introducidas de forma no consciente, es algo imposible de saber. Sin embargo, han quedado registradas, fusionando plenamente dos culturas. Por una parte, los textos básicos del cristianismo se traducen a lenguas mesoamericanas y, por otra, a estos se les decora con motivos indígenas.

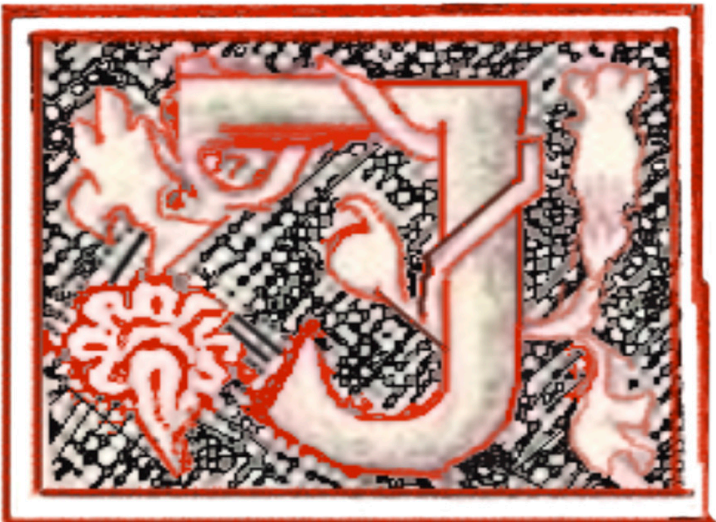

Figura 13. Capitular con flor de rasgos prehispánicos, ms. Tl. Figure 13. Initial letter with flower with prehispanic features, $m s$. Tl.

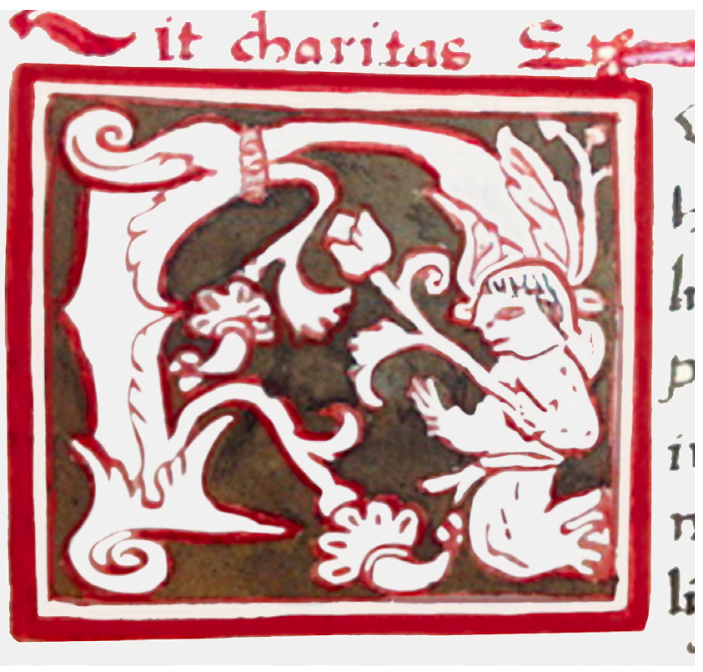

Figura 14. Capitular, ms. Mx, fol. 5r. Figure 14. Initial letter, ms. $M x, p .5 r$.

Como se ha visto, lo propiamente europeo adquiere rasgos y significados novedosos.

Además de ser un testimonio de la interpolación cultural indígena, el estudio de los elementos iconográficos en los códices litúrgicos mesoamericanos nos permite conocer otras facetas acerca de su propia elaboración, ya que, como hemos visto, la revisión de los ornatos nos puede indicar cuestiones acerca de quienes manufacturaron los códices, pues algunos, además de compartir ciertos rasgos, tienen elementos idénticos, lo que nos lleva a suponer que fueron realizados por una misma persona en un tiempo determinado, y nos ayuda a circunscribir 


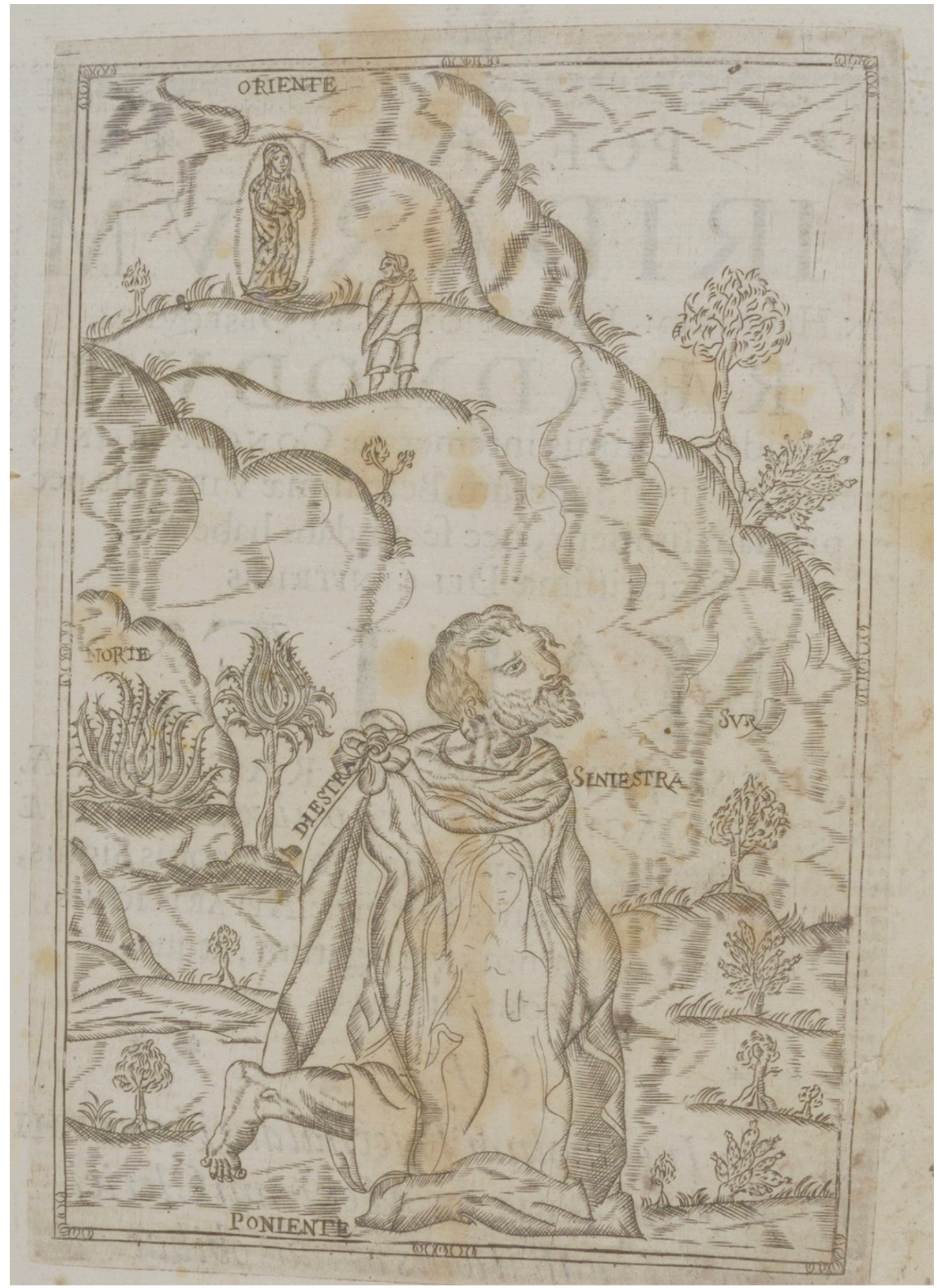

Figura 15. Grabado Juan Diego. (López de Avilés 1669, ejemplar de la Biblioteca Newberry). Figure 15. Juan Diego engraving (López de Avilés, J., 1669, copy from the Newberry Library). 
los manuscritos a una misma época y región. Asimismo, encontrar algunos motivos específicos nos podrían acercar al arquetipo utilizado por los amanuenses indígenas en la elaboración de los evangeliarios.

Finalmente, si ya se sabía, además, que colegiales autóctonos como Pablo Nazareo, de Xaltocan, o Hernando de Ribas, de Texcoco, fueron importantes en la elaboración de obras como el Evangeliario en lengua mexicana o los Coloquios de Gaona, ahora sabemos que otros colaboradores pudieron plasmar su sello personal en estas obras.

Dado que hasta ahora es muy poco lo que se sabe de los evangeliarios y textos litúrgicos, es imprescindible abordar el análisis de ellos desde diferentes perspectivas: lingüística, codicológica, iconográfica, entre otras. Este primer acercamiento es una invitación para reflexionar sobre las diversas posibilidades de análisis de los textos litúrgicos y su interpretación iconográfica.

\section{Siglas y relación de obras analizadas}

$T l$ Ms. 35-22, Epistolas y Evangelios en lengua mexicana, Biblioteca Capitular de Toledo.

MS Ms. 1482, Sermonario en lengua mexicana, Biblioteca Nacional de México

Mx Ms. 1482, Epístolas y Evangelios en lengua mexicana (fragmento), Biblioteca Nacional de México

Nw Ms. Epístolas y Evangelios en lengua mexicana, Biblioteca Newberry, Chicago.

Mt Ms. Epistolas y Evangelios en lengua mexicana (fragmento), Biblioteca del Tecnológico de Monterrey.

$B w$ Ms. Cod. Ind. 23. Contemptus mundi, Biblioteca John Carter Brown.

\section{NOTAS}

${ }^{1}$ No todas las obras religiosas son litúrgicas. Estas son exclusivamente aquellas que se utilizan en la ceremonia de la misa; las religiosas pueden ser doctrinales, teológicas, paralitúrgicas, entre otras. Sobre la ceremonia de la misa en lenguas indígenas prácticamente no hay datos. Sobre el tema religioso en lenguas indígenas, por el contrario, tenemos numerosa bibliografía, cf. nota 6 .

${ }^{2}$ Todos los dibujos (formato digital: Gimp2), ilustraciones y fotografías fueron realizadas por la autora, excepto aquellas que se han tomado de códices y manuscritos que se encuentran disponibles en línea ("Public Domain") y que están pertinentemente identificados.
${ }^{3}$ Un extenso catálogo de las obras latinas anteriores al siglo x se encuentra en Gamber 1968; en tanto, la Biblioteca Británica (http://www.bl.uk/onlinegallery/onlineex/illmanus/index.html) cuenta con una exposición digital con más de tres mil imágenes de manuscritos iluminados del siglo VIII al Xv. Las bibliotecas Vaticana, Capitular de Toledo, Veronense, Nacional de Francia, entre muchas otras, poseen también una rica colección de códices litúrgicos ilustrados.

${ }^{4}$ Para un acercamiento a la forma de creación, elaboración y detalles de los primitivos libros, cf. Morgan \& Thomson 2008.

${ }^{5}$ En Gameson (2011) se presentan diversos artículos sobre la elaboración, composición y análisis de manuscritos y libros medievales. Para este artículo se han revisado especialmente aquellos sobre evangeliarios y textos bíblicos.

${ }^{6}$ Sobre la evangelización y las obras religiosas de la Nueva España hay una extensa bibliografía: Burkhardt 1991, Lara 2008, Tavárez 2013, Christensen 2013, entre otros.

${ }^{7}$ Los primeros evangelizadores fueron los franciscanos (1523), quienes, antes de dominar las lenguas mesoamericanas, utilizaron métodos doctrinales rudimentarios, como los catecismos pictográficos o "testerianos". Más tarde, al aprender las lenguas vernáculas y codificarlas según el alfabeto latino comenzaron a escribir las obras en lenguas regionales (Ricard 2000: 192).

${ }^{8}$ El tonalpohualli era el calendario de 260 días, como se explica. Por el contrario, el xiuhpohualli era la cuenta de los años de 360 días. Ambos calendarios coincidían al terminar el ciclo de 52 años, y el desfase respecto al ciclo solar se resolvía añadiendo trece días, tomando a Venus como referencia. Conferencia magistral, Jesús Galindo, 18-02-2019, Ciclo “Tradiciones Bíblicas: de la Antigüedad al Nuevo Mundo". México, Universidad Nacional Autónoma de México.

${ }^{9} \mathrm{El}$ énfasis en esta cita y en las subsiguientes son de la autora.

${ }^{10}$ La narración señala que Oxomoco y Cipactonal habrían inventado el sistema para contar los días señalando los objetos que estaban a su alcance, comenzando por cipactli, tras lo cual "el marido de la vieja puso dos cañas y el nieto tres casas, etc., de esta manera fueron poniendo hasta trece signos en cada plana" (Mendieta 1870: Libro II, Capítulo 14).

${ }^{11}$ Queda por analizar si este binomio tlachco-cuauhtli tiene algún significado más, o si, incluso, proporciona datos sobre el amanuense, como el nombre, la fecha u otra cuestión. Finalmente, este símbolo se puede comparar con los códices medievales donde aparecen figuras animales, aunque evidentemente, en ninguno se encuentra un tlachco.

${ }^{12}$ De acuerdo con Molina (1571b: 28v) eloizhuatl es la 'camisa' de maíz verde, mientras que el elotl es la mazorca de maíz verde 'que tiene ya cuajados los granos', mientras que elototomochtli es lo mismo que eloizhuatl. Cabe destacar que el propio uso de 'maíz' es una novedad léxica americana (del taíno mahís, RAE)

${ }^{13}$ Es el caso del "Códice Xochimilco Plano de Varias Propiedades" (Ms. mexicanos 34, BNF) tal como aparece en 
el Diccionario de glifos de la página "Amoxcalli" (https:// amoxcalli.org.mx/diccionario.php). En otras representaciones se puede ver toda la mazorca con los granos en la parte superior, y en el medio un ojo, de esto hay numerosas representaciones analizadas por Castillo Trejo (2009).

${ }^{14}$ El manuscrito de la Biblioteca Capitular de Toledo 3522, descubierto en 2012 por Téllez y Baños (2018) comparte numerosas características con nueve folios dispersos que se encuentran con el Sermonario en lengua mexicana (ms. 1482, BNM). Estos últimos parecen coincidir con la fecha de elaboración del manuscrito toledano (1544) y es probable que se realizaran al mismo tiempo. En breve publicaremos un análisis sobre estos folios.

\section{REFERENCIAS}

Blázquez Martínez, J. M. 1997. El cristianismo, religión oficial. Historia 16: 56-65.

BurcKhardT, T. 2006. The foundations of christian art. World Wisdom: M. O. Fitzgerald.

Burkhart, L. M. 1989. The slippery Earth. Nahua-christian moral dialogue in sixteenth-century Mexico. Tucson: University of Arizona Press.

Burkhart, L. M. 1991. A nahuatl religious drama. Latin American Indian Literatures Journal 7: 153-171.

Christensen, M. Z. 2013. Nahua and maya catholicisms. Texts and religion in colonial central Mexico and Yucatan. California: Stanford University Press-The Academy of American Franciscan History.

De la Fuente, B. 1995. La pintura mural prehispánica en México. Mexico City: Universidad Nacional Autónoma de México.

De la Garza, M. 1984. El universo sagrado de la serpiente entre los mayas. Mexico City: Universidad Nacional Autónoma de México.

De la Garza, M. \& IzQUierdo A. L. 1980. El Ullamaliztli en el s. Xvi. Estudios de Cultura Náhuatl 14: 315-333.

De Mendieta, J. 1870 [1596]. Historia eclesiástica indiana. Mexico City: Antigua Librería.

De Molina, A 1571a. Vocabulario en lengua castellana y mexicana. Mexico City: Antonio de Spinoza.

De Molina, A. 1571b. Vocabulario en lengua mexicana y castellana. Mexico City: Antonio de Spinoza.

Dibble, C. 1974. The nahuatlization of christianity, in sixteenthcentury Mexico: the work of Sahagun. Albuquerque: University of New Mexico Press.

Gamber, K. 1968. Codices liturgici latini antiquiores. Freiburg Schweiz: Universitätsverlag.

Gameson, R. (Ed.) 2011. The Cambridge history of the book in Britain, vol. 1: c. 400-1100. Cambridge: Cambridge University Press.

GRUZINSKI, S. 2016. La colonización de lo imaginario: sociedades indígenas y occidentalización en el México español, siglos XVI-XVIII. Mexico City: Fondo de Cultura Económica.
Johansson, P. 2008. Cempoallapohualli. La cronología de las veintenas en el calendario solar náhuatl. Estudios de Cultura Náhuatl 39: 149-184.

LARA, J. 2008. Christian texts for aztecs: art and liturgy in colonial Mexico. Notre Dame: University of Notre Dame Press.

López Austin, A. 1967. Juegos rituales aztecas. Mexico City: Universidad Nacional Autónoma de Mexico.

López Austin, A., López, L. \& Sugiyama, I. S. 1991. El templo de Quetzalcoatl en Teotihuacan. Su posible significado ideológico. Anales del Instituto de Investigaciones Estéticas 16 (62): 35-52.

López DE Avilés, J. 1669. Nuestra Señora de Guadalupe aparecida en México. Centunculus rigorosus, in laudem purissimae... Sanctissimae Virginis. Mexico City: Bernardi Calderon para Pedro de Quiñones.

López Ramírez, M. C. 2015. Usos y desusos de la letra capitular (del códice medieval a la marca corporativa). Tesis para optar al grado de Doctora en Bellas Artes y Nuevas Tecnologías, Universidad de Málaga <https://core.ac.uk/ reader/62908770> [consultado: 15-03-20].

Moreno de los Arcos, R. 1969. Guía de las obras en lenguas indígenas existentes en la Biblioteca Nacional, Boletín de la Biblioteca Nacional xviI (1-2): 21-210.

Morgan, N. \& Thomson, R. (Eds). 2008. The Cambridge History of the book in Britain. Volumen 2. Cambridge: Cambridge University Press.

Mundy, B. 2018. El artista indígena y su encuentro con el Renacimiento. In El Renacimiento italiano desde América Latina, C. Bargellini \& P. Díaz, Eds., pp. 38106. Mexico City: Universidad Nacional Autónoma de México. <http://www.librosoa.unam.mx/xmlui/ bitstream/handle/123456789/1807/e18796f3d84e65a9ed0aecf4976493cc.epub? sequence $=3$ \&isAllowed $=y>$ [consultado: 15-03-20].

Mundy, B. E. \& Leibsohn, D. 2012. History from things: indigenous objects and colonial Latin America. World History Connected. $<$ http://worldhistoryconnected.press.illinois. edu/9.2/forum_mundy.html> [consultado: 22-11-16].

Piñero, A. 2007. Los cristianismos derrotados. Madrid: EDAF.

Reyes-VAlerio, C. 1989a. Arte indocristiano. Escultura del siglo XVI en México. Mexico City: Instituto Nacional de Antropología e Historia.

Reyes-Valerio, C. 1989b. Las pictografías nahuas en el arte indocristiano. In Primer Coloquio de documentos pictográficos de tradición náhuatl, C. Martínez Marín, Ed., pp. 71-80. Mexico City: Universidad Nacional Autónoma de México.

RicARD, R. 2000. La conquista espiritual de México. Mexico City: Fondo de Cultura Económica.

Roberts, C. H. 1979. Manuscript, society and belief in early christian Egypt (The Schweich Lectures 1977). London: The British Academy.

SAHAGún, B. [ca.]1577. Historia general de las cosas de la Nueva España. Biblioteca Digital Mundial. <https://www.wdl. org/es/item/10615 > [consultado: 15-03-20]. 
Sánchez Mairena, A. 2015. Selección bibliográfica de investigaciones sobre manuscritos litúrgicos en España. Memoria Ecclesiae xxxıx: 616-683. Oviedo: Asociación de Archiveros de España.

SÉJOURNÉ, L. 1983. El pensamiento náhuatl cifrado por los calendarios. Mexico City: Siglo XxI.

TAladoire, E. 2017. Cinco tesis discutibles relativas al juego de pelota. Arqueología mexicana 50: 191-209.

TAváREZ, D. 2013. A banned sixteenth-century biblical text in nahuatl: the proverbs of Solomon. Ethnohistory 60 (4): 769-772.

TAvÁrez, D. 2013. Nahua intellectuals, franciscan scholars and the devotio moderna in colonial Mexico. The Americas 70 (2): 203-235.

TÉLlez Nieto, H. 2016. La tradición textual latina de las Fábulas de Esopo en lengua náhuatl. Latomus, Revue détudes latines 74 (3): 715-734.
TÉLlez Nieto, H. 2019. Latinidad, tradición clásica y nova ratio en el Imperial Colegio de la Santa Cruz de Santiago Tlatelolco. JOLCEL 2: 30-55.

Téllez Nieto, H. \& Baños Baños, J. M. 2018. Traducciones bíblicas en lenguas indoamericanas: el evangeliario náhuatl de la Biblioteca Capitular de Toledo (mss. 35-22). Revue d'Histoire Ecclésiastique 113 (3/4): 656-689.

Thouvenot, M. 2005. El elemento calli 'casa' y las diversas unidades territoriales. Memoria textual indígena: elementos de su escritura. Diario de Campo 35: 92-113.

Uriarte, T. 1992. El juego de pelota en Mesoamérica: raíces y supervivencia. Mexico City: Siglo XxI.

Viseo, J. B. 1606. Sermonario. Mexico City: Diego López Dávalos. 